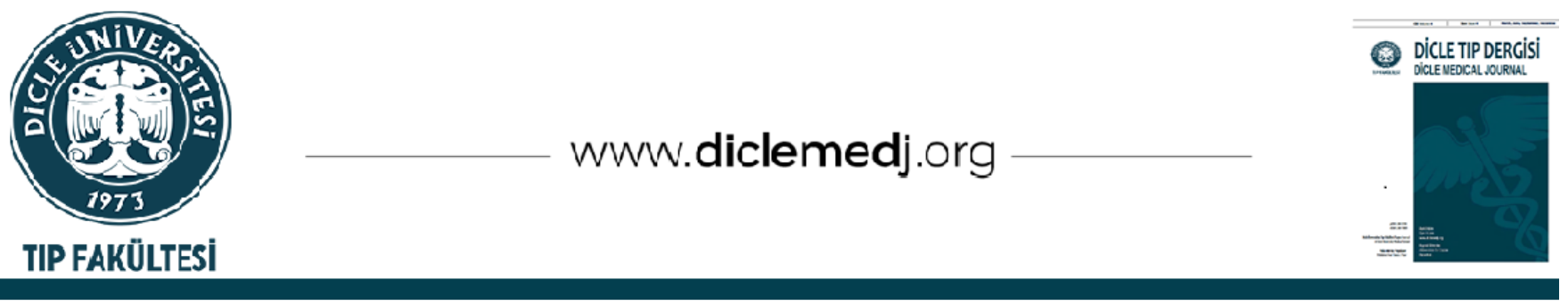

Original Article / Özgün Araştırma

\title{
Comparison of the Analgesic Effects of Ultrasound Guided Pectoral Nerve Block Type II and Erector Spinae Plane Block in Breast Cancer Surgery
}

\author{
Mustafa Bicak ${ }^{1}$, Fikret Salik ${ }^{1} 1$ \\ 1 Gazi Yaşargil Training and Research Hospital, Anesthesiology and Reanimation Clinic, Diyarbakir, Turkey.
}

Received: 12.07.2021; Revised: 08.09.2021; Accepted: 15.09.2021

\begin{abstract}
Objectives: To compare the effect of ultrasound guided Pectoral Nerve Block 2 (PECs 2) and Erector Spinae Plane Block (ESP) for post op analgesia in patients undergoing Breast cancer surgery

Methods: This observationally planned study included 40 patients over the age of ages of 18 who are of American Society of Anesthesiologists (ASA) I-III and scheduled for elective surgery due to breast malignancy were included in the study. PECs 2 block was applied to the patients after the induction of general anesthesia in Group 1 and ESP block was applied to the patients after the induction of general anesthesia in Group 2. In the postoperative period, visual analog scale (VAS) values, nausea, vomiting and sedation score values and analgesic doses used by all patients in the post-operative period were recorded.
\end{abstract}

Results: Intraoperative and postoperative opioid consumption was statistically significantly lower in the PECs block group than in the ESP group. Postoperative analgesia time was longer in the PECs group. The number of patients requiring rescue opioid in the post-operative period was statistically significantly lower in the PECs group. There was no difference between the groups in terms of complications, mobilization time, time of discharge, postoperative nauseavomiting (PONV) and terms of sedation.

Conclusions: In patients who underwent breast surgery for malignancy, we found that the ultrasound (US) guided PECs 2 block achieved more effective postoperative analgesia compared to ESP block.

Keywords: Breast surgery, Erector Spinae Plane Block, Pain management, Pectoral Nerve Block 2

DOI: 10.5798/dicletip.999785

Correspondence / Yazıșma Adresi: Mustafa Bicak, GaziYaşargil Training and Research Hospital, Anesthesiology and Reanimation Clinic, Diyarbakir, Turkey.e-mail: drmustafabicak@gmail.com 


\section{Meme Kanseri Cerrahisinde Ultrasonografi Eşliğinde Pektoral Sinir Bloğu Tip 2 ve ErektörSpina Plan Bloğunun Analjezik Etkilerinin Karşılaştırılması}

Öz

Amaç: Meme kanseri cerrahisi geçiren hastalarda post operatif analjezi için ultrasonografi rehberliğinde uygulanan Pektoral Sinir Bloğu 2 (PECs 2) ve Erektör Spina Plan bloğunun (ESP) etkilerini karşılaştırmak.

Yöntemler: Gözlemsel olarak planlanmış bu çalıșmaya, 18 yaş üstü, American Society of Anesthesiologists skoru (ASA) I-III olan ve meme malignitesi nedeniyle elektif cerrahi planlanan 40 hasta dahil edildi. Grup 1'deki hastalara genel anestezi indüksiyonu sonrası PECs 2 blok, Grup 2'deki hastalara ise genel anestezi indüksiyonu sonrası ESP blok uygulandı. Postoperatif dönemde vizüel analog skala (VAS) değerleri, bulantı, kusma ve sedasyon skor değerleri kaydedildi. Ayrıca postoperatif dönemde tüm hastaların kullandı̆̆ı analjezik dozları kayıt altına alındı.

Bulgular:İntraoperatif ve postoperatifopioid tüketimi, PECs 2 blok grubunda ESP grubuna göre istatistiksel olarak anlamlı derecede düşük bulundu. PECs 2 blok grubunda postoperatif analjezi süresi daha uzun bulundu. Postoperatif dönemde kurtarıcı opioid kullanımına ihtiyaç duyan hasta sayısı PECs 2 blok grubunda istatistiksel olarak anlamlı derecede düşüktü. Gruplar arasında komplikasyon, mobilizasyon süresi, taburcu olma zamanı, postoperatif bulantıkusma (POBK) ve sedasyon skorları açısından fark saptanmadı.

Sonuç: Malignite nedeniyle meme cerrahisi uygulanan hastalarda ultrasonografi (USG) eşliğinde uygulanan PECs-2 blok uygulamasının ESP blok uygulamasına göre daha etkili postoperatif analjezi sağladığını saptadık.

Anahtar kelimeler: Meme cerrahisi, ErektörSpina Plan Bloğu, Ağrı yönetimi, Pektoral Sinir Bloğu 2.

\section{INTRODUCTION}

One out of every nine women across the world is diagnosed with breast cancer in their lives ${ }^{1}$. This rate is increasing day by day due to lifestyle changes and environmental factors ${ }^{2}$. As in the world, breast cancer is the most common type of cancer in women in Turkey².

Although the complementary role of medical treatments in breast cancer is high, surgical treatment with breast-conserving surgery, modified radical mastectomy and axillary lymph node dissection is also of significant importance. Although the postoperative pain in patients varies depending on the type of surgery, it is seen in moderate to severe levels ${ }^{3}$. Failure to achieve successful pain control in the early postoperative period might result in increased opioid consumption, delayed wound healing, decreased patient satisfaction, longer hospital stays and chronic pain ${ }^{4}$. Multimodal analgesia methods including regional anesthesia techniques that utilize steroid antiinflammatory agents, opioids, thoracic epidural anesthesia and paravertebral blocks are used.
Thanks to the widespread use of the Enhanced Recovery After Surgery (ERAS) protocol, the frequent use of ultrasonography, and the new block techniques, anesthetists can achieve more successful results in postoperative pain control. Pectoral Nerve Block 2 (PECs 2) and Erector Spinae Plane (ESP) blocks are among the multimodal analgesia techniques that have found more frequent use in pain management after breast surgery and whose success in pain control has been supported by many studies ${ }^{4-7}$.

In this study, we aimed to compare the effectiveness of PECs 2 block and ESP block applications for post-operative pain control in patients who underwent surgery for breast cancer.

\section{METHODS}

\section{Patients}

The study was planned to be conducted as a prospectively observational one between the dates 01.03.2020-01.03.2021. The approval of the local ethics committee (28.02.2020-436) was obtained. Forty-four patients over the age 
of 18 who are of American Society of Anesthesiologists skoru (ASA) I-III and scheduled for elective surgery due to breast malignancy were included in the study. The exclusion criteria included refusal to participate in the study, infection in the area to be applied, coagulopathy, morbid obesity (body mass index (BMI) > 35), history of drug allergy, history of chronic pain, history of long-term opioid use, history of psychiatric disease, history of tumor and surgery that spread to the application area, history of recurrent surgery, and history of radiotherapy and emergency surgery. One patient was excluded due to morbid obesity, 1 patient due to history of chronic drug use (codeine), and 2 patients due to history of radiotherapy. The study was completed with 40 patients (Figure 1).

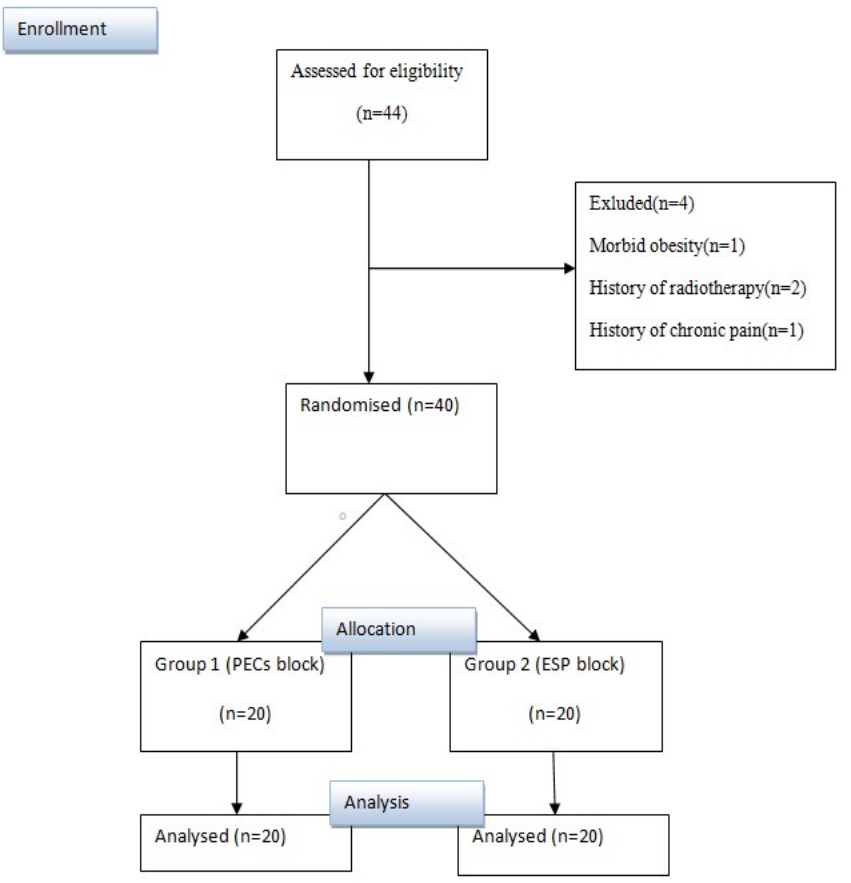

Figure 1: Flow diagram

The patients were evaluated in the service by an experienced anesthesiologist in the preoperative period. Detailed information was given about the surgical procedure and block applications to be performed. Written informed consent forms were obtained from all patients. The patients were informed about the Visual
Analogue Scale (VAS $0=$ no pain, $10=$ the worst pain imaginable) used in the evaluation of postoperative pain. PECs 2 block was applied to the patients in Group 1 and ESP block was applied to the patients in Group 2.

\section{Procedures}

The patients were taken to the operating room. Electrocardiography, peripheral oxygen saturation and non-invasive blood pressure monitoring were performed in accordance with the standards of the American Society of Anesthesiologists. 30 minutes before the surgery, 2 vascular accesses were established in the antecubital area with a 20 Gauge cannula in all patients. In the induction of anesthesia, the patients were administered intravenously 0.1 $\mathrm{mg} / \mathrm{kg}$ midazolam, 2-3 $\mathrm{mg} / \mathrm{kg}$ propofol, 1 $\mathrm{mcg} / \mathrm{kg}$ fentanyl and $0.6 \mathrm{mg} / \mathrm{kg}$ rocuronium. The patients were intubated through the orotracheal route. Anesthesia maintenance of the patients after intubation was provided with 1 minimum alveolar consantration (MAC) sevoflurane in $50 \%$ air. The patients were followed up with a volume-controlled mode, keeping end-tidal carbon dioxide values in the $30-35 \mathrm{mmHg}$ range. All block applications were completed after general anesthesia induction and 15 minutes before the skin incision. After the induction of general anesthesia, PECs 2 blocks were applied to the patients in Group 1 under sterile conditions, accompanied by a linear ultrasound (US) probe (Mindray DP-50). During the block application, first of all, the musculus pectoralis major and minor were spotted in the midclavicular line. Then the axillary artery was visualized by directing the probe inferolaterally. This level was determined as the rib-2 level and progressed towards the inferolateral. The in-plane technique was used to cross the skin and subcutaneous tissue at the levels of rib-3 and rib-4 using a $100 \mathrm{~mm}$ block needle (Braun stimuplex22 gauge peripheral nerve block needle). The distribution of the anesthetic agent was checked, and 10 cc of 
$0.25 \% \mathrm{mg} / \mathrm{ml}$ bupivacaine was administered between the muscles pectoralis major and minor. Afterwards, the needle was advanced deeper, and $20 \mathrm{cc}$ of $0.25 \% \mathrm{mg} / \mathrm{ml}$ bupivacaine was administered between the muscles pectoralis minor and serratus anterior (Figure 2-4).

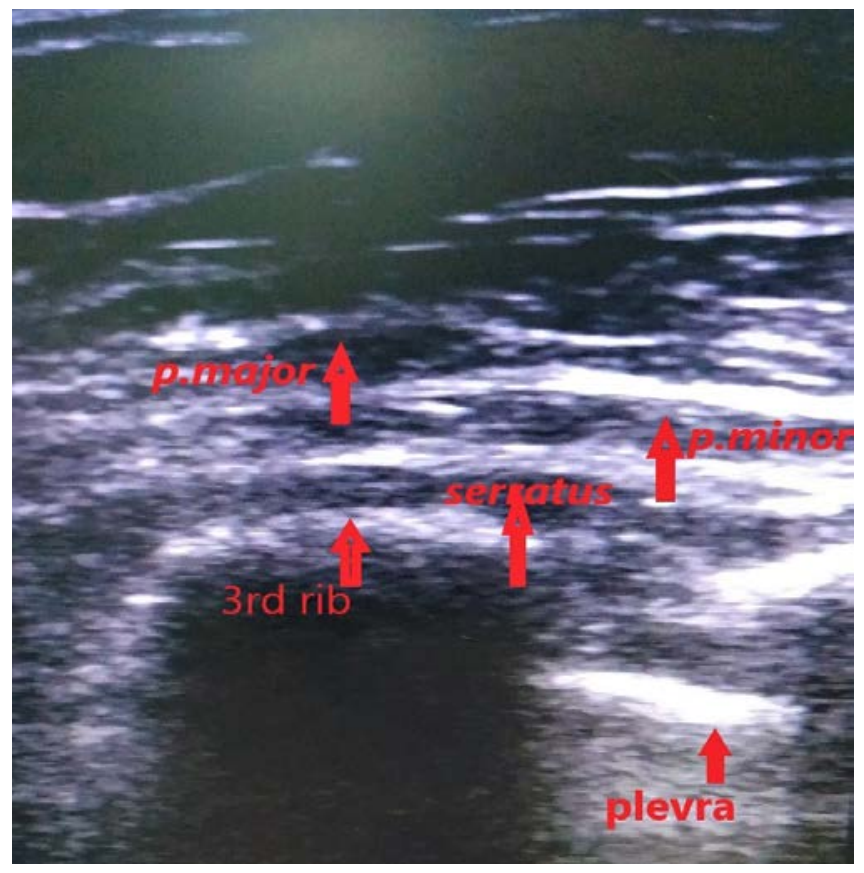

Figure 2: US view of pectoral region

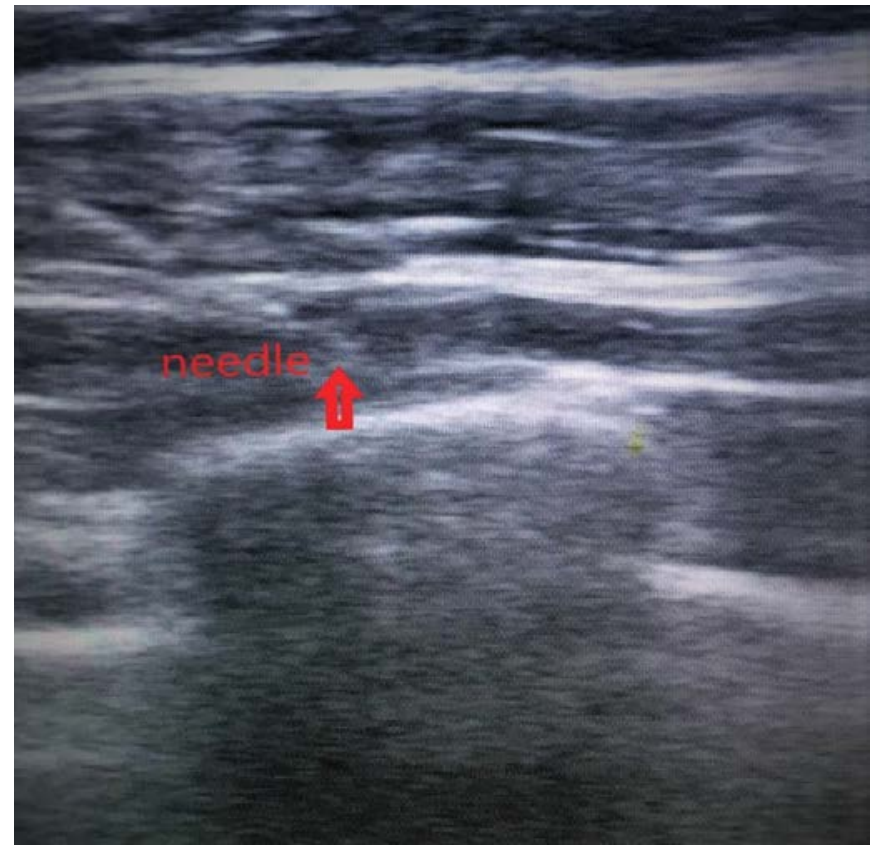

Figure 3: Needle insertion between musculus serratus anterior and musculus pectoralis minor

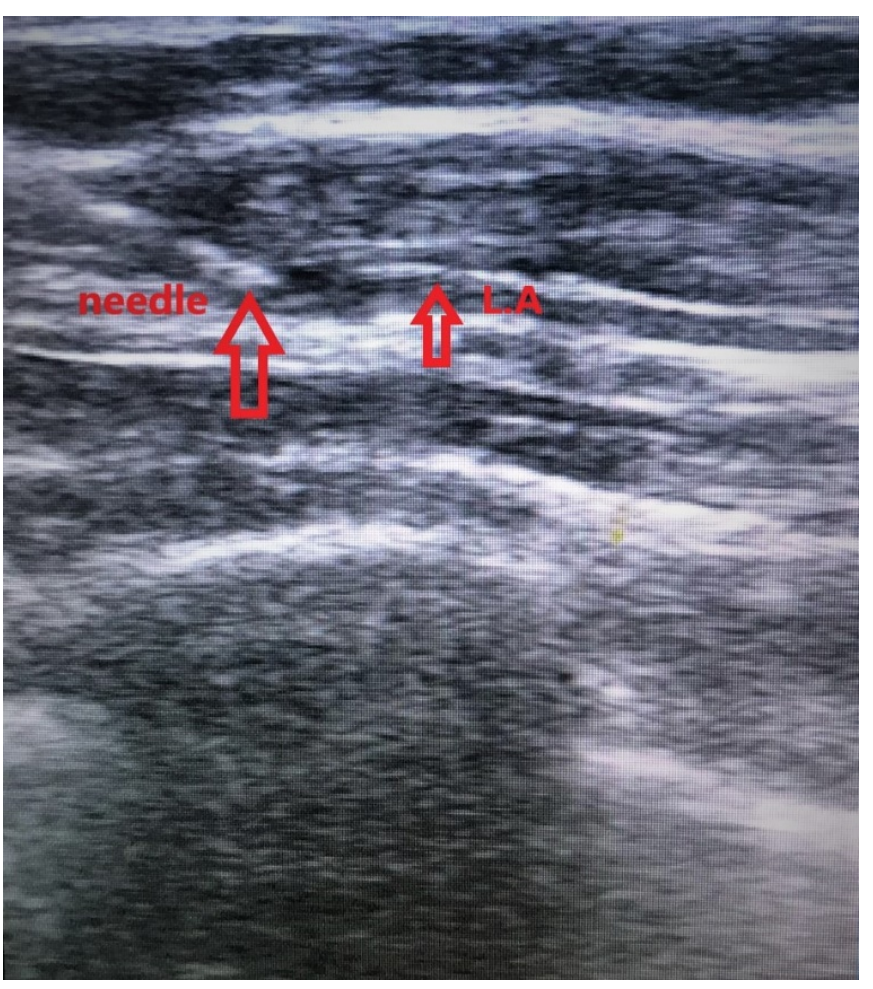

Figure 4: View of completed PECs 2 block

Abbreverations: LA; Local Anesthetic

The patients in Group 2 were applied ESP block at lateral decubitus position after the general anesthesia induction as described by Chin et al. in their study ${ }^{8}$. T4 level was determined during block application, after the skin was cleaned, the convex ultrasound probe (Mindray DP-50) was placed laterally $2-3 \mathrm{~cm}$ from the midline and the erector spinae muscle and the $\mathrm{T} 4$ transfer process were spotted. The block needle (Braun stimuplex22 gauge peripheral nerve block needle) was guided from the cranial to the caudal to contact the transfer process, then the needle was pulled back a little and after confirming the location of the needle with 1-1.5 $\mathrm{ml}$ of saline, a local anesthetic agent solution that contains $20 \mathrm{ml}$ of $0.25 \% \mathrm{mg} / \mathrm{ml}$ bupivacaine was administered (Figure 5). In previous studies, it was found that the ESP block application with $20 \mathrm{ml} 0.25 \%$ bupivacaine at $\mathrm{T} 4$ level provides effective pain control after breast surgery ${ }^{9}$. That is why we used the same dose in our study. All blocks were performed by the same experienced anesthesiologist, and no 
patient exceeded the toxic dose of $3 \mathrm{mg} / \mathrm{kg}$ bupivacaine.

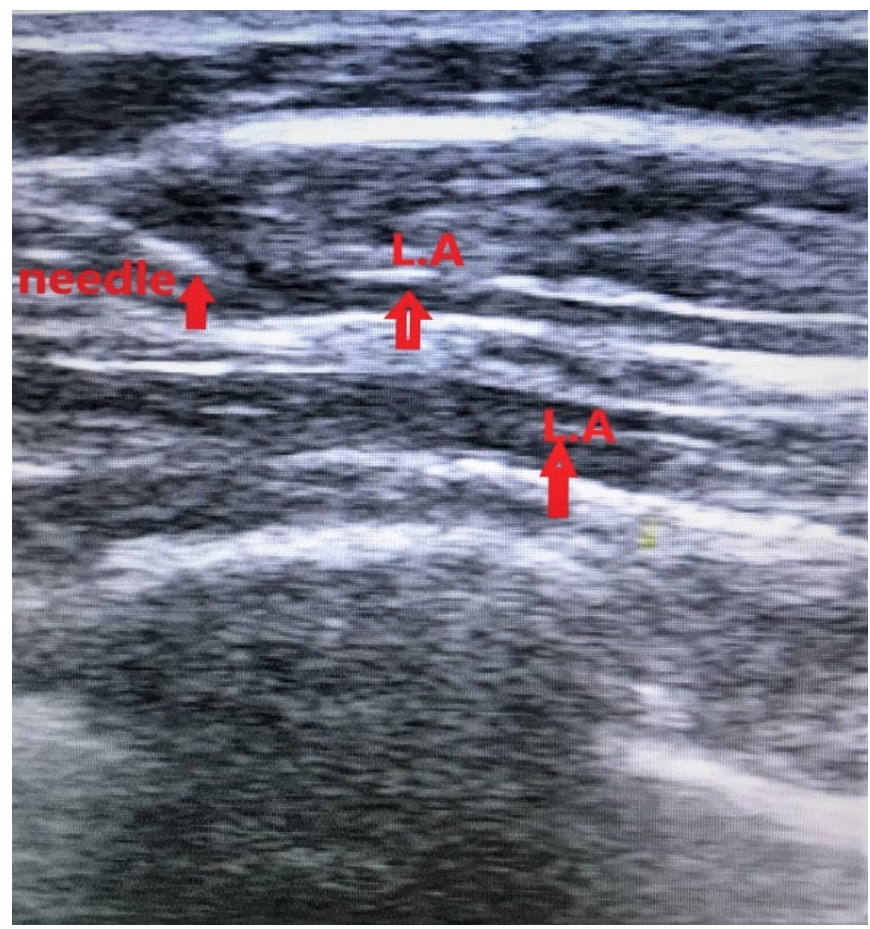

Figure 5: US view of ESP Block area

In all patients, $1 \mathrm{mcg} / \mathrm{kg}$ iv fentanyl was administered when the mean arterial pressure increased $20 \%$ compared to the basal value during the maintenance of anesthesia and was recorded as the amount of opioid consumed intraoperatively. At the end of the surgery, paracetamol $10 \mathrm{mg} / \mathrm{kg}$ IV infusion was administered. All patients received $1 \mathrm{~g}$ of paracetamol intravenously, with 8-hours intervals in the post-operative period.

The patients were administered $0.06 \mathrm{mg} / \mathrm{kg}$ neostigmine after the surgery was completed, and those patients with sufficient muscle strength and respiratory function were extubated and transferred to the postoperative follow-up unit.

Intravenous 1mg / $\mathrm{kg}$ tramadol was administered to patients with a visual analog scale (VAS) value of $>4$ and recorded. If the patient's pain scores did not decrease $(<4)$ within 30 minutes despite tramadol administration, intravenous (iv) tramadol repetition at $1 \mathrm{mg} / \mathrm{kg}$ dose was planned.

\section{Outcomes}

In the postoperative period, the at-rest and onmovement VAS scores of the minute 30 , the 1st, 2nd, 4th, 8th, 12th, 24th hours and the 1st week were examined and recorded. To measure the onmovement VAS scores, the patients were asked to cough and abduct their arm at 900 . Those found to have VAS $\geq 4$ were administered iv $1 \mathrm{mg} / \mathrm{kg}$ tramadol and its record was kept. If no relief was observed within 30 minutes despite the administration of tramadol in the patient, $1 \mathrm{mg} / \mathrm{kg}$ tramadol was repeated. Those patients who received rescue opioids and the time of administration were recorded. The average amount of opioids used was calculated.

In the post-operative period, nausea and vomiting were evaluated and recorded on a 3-point scale $(0=$ absent, $1=$ mild, $2=$ severe). Intravenous 0.15 $\mathrm{mg} / \mathrm{kg}$ ondansetron was administered to the patients with nausea or vomiting score of 1 and above. In the postoperative period, the sedation score was evaluated at the 1st, 2nd, 4th, 8th, 12th, 16th and 24th hours with a 3-point scale (awake $=0$, sleepy $=1$, deeply sleepy $=2$ ) and recorded.

\section{Statistical Analysis}

In calculating the sample size, G-Power version 3.1.9.4 (University of Kiel, Kiel, Germany) program was used with reference to the rates stated in previous studies ${ }^{10}$. SPSS 16.0 for Windows program (SPSS Inc., Chicago, IL, USA) was used for statistical analysis. Statistical data were expressed as mean and standard deviation, while categorical data were expressed as frequency and percentage. Comparison of categorical data in the groups was done with chisquare and fisher's exact tests, the results were given as $\% \mathrm{n}$. The Kolmogorov-Smirnov test was used to determine if the numerical data fit the normality distribution. While the data matching the normality distribution were evaluated with the Oneway ANOVA test, the Kruskal-Wallis test was used to compare the data that did not meet the normality distribution. In all comparisons $\mathrm{p}<0.05$ was considered significant.

\section{RESULTS}


A total of 40 patients, including 20 patients in each group, were included in the study. The clinical characteristics of the patients are shown in Table 1. There was no difference between the groups in terms of age, BMI, presence of co-morbidity and duration of surgery (Table 1 ).

Table I: Patient characteristics

\begin{tabular}{|lccc|}
\hline & $\begin{array}{l}\text { PECs } \\
\text { group } \\
\end{array}$ & $\begin{array}{l}\text { ESP } \\
\text { group } \\
(\mathrm{n}=20)\end{array}$ & pvalue \\
& $(\mathrm{n}=20)$ & \\
\hline Age (year) & $57.8 \pm 9,4$ & $52.7 \pm 14,0$ & 0.185 \\
BMI (kg/cm $\left.{ }^{2}\right)$ & $28.2 \pm 3,7$ & $25.6 \pm 3,7$ & 0.035 \\
Co-morbidity (n) & $12(60)$ & $9(45)$ & 0.342 \\
Surgery time (min) & $112.5 \pm 23.1$ & $105.5 \pm 13.9$ & 0.254 \\
\hline
\end{tabular}

BMI; Body mass index

Intraoperative and postoperative opioid consumption was statistically significantly lower in the PECs 2 block group than in the ESP group ( $p=0.028$ and 0.017) (Figure 6). Postoperative analgesia time was longer in the PECs 2 group ( $p<0.001)$. The number of patients requiring rescue opioid in the postoperative period was statistically significantly lower in the PECs 2 group ( $p<0.001)$. There was no difference between the groups in terms of complications, mobilization time and time of discharge (Table 2).

Table II: Total opioid consumption and duration of analgesia

\begin{tabular}{|c|c|c|c|}
\hline & $\begin{array}{l}\text { PECs } \\
\text { group } \\
(n=20)\end{array}$ & $\begin{array}{l}\text { ESP } \\
\text { group } \\
(\mathrm{n}= \\
20)\end{array}$ & $\begin{array}{l}\mathrm{p} \\
\text { value }\end{array}$ \\
\hline Intraoperativeopioidconsumption (mcg) & $17.5 \pm 28,2$ & $42.5 \pm 39,8$ & $0.028^{*}$ \\
\hline Postoperativeopioidconsumption (mg) & $12.5 \pm 39,3$ & $43.7 \pm 39,6$ & $0.017^{*}$ \\
\hline Duration of analgesia (hour) & $22.4 \pm 4,9$ & $11.1 \pm 10,6$ & $<0.001$ \\
\hline Postoperativerescueanalgesia (Yes/No) & $1 / 19$ & $8 / 12$ & $<0.001^{*}$ \\
\hline Complication (n) & $3(15)$ & $5(25)$ & 0.429 \\
\hline Mobilization time (hour) & $4.2 \pm 0.5$ & $4.3 \pm 0.9$ & 0.552 \\
\hline Discharge time (hour) & $27.8 \pm 11,7$ & $25.2 \pm 2,2$ & 0.339 \\
\hline
\end{tabular}

*statistically significant
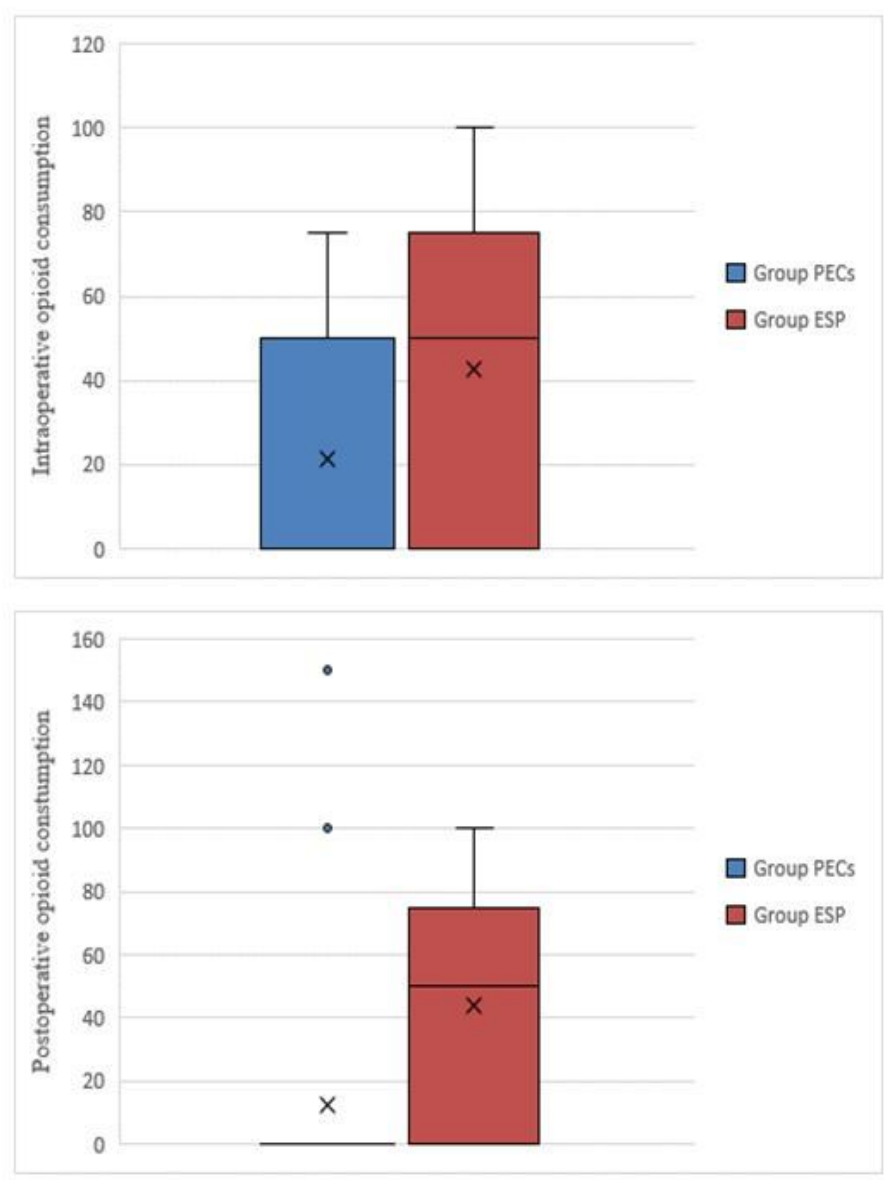

Figure 6: Intraoperative and postoperative opioid consumption in both groups

There was no statistically significant difference between the groups in terms of at-rest VAS scores. The on-movement VAS scores (when coughing and with ipsilateral arm at 900abduction) of the post-operative first 4-hour period were statistically lower in the PECs 2block group than in the ESP block group (p values $0.007,0.035,0.022$ and 0.005 , respectively) (Table 3). 
Table III: Visual analog scale scores at rest and movement (mean \pm SD (min-max)

\begin{tabular}{|c|c|c|c|}
\hline & $\begin{array}{l}\text { PECs } \\
\text { group } \\
(\mathrm{n}=20)\end{array}$ & $\begin{array}{l}\text { ESP } \\
\text { group } \\
(\mathrm{n}=20)\end{array}$ & $\begin{array}{l}\mathrm{p} \\
\text { value }\end{array}$ \\
\hline \multicolumn{4}{|l|}{ At rest } \\
\hline 30.min & $1.0(0-3)$ & $1.5(0-3)$ & 0.098 \\
\hline 1.hour & $0.9(0-3)$ & $1.5(0-3)$ & 0.065 \\
\hline 2.hour & $1.2(0-4)$ & $2.0(0-5)$ & 0.118 \\
\hline 4.hour & $0.9(0-2)$ & $1.7(0-6)$ & 0.057 \\
\hline 8.hour & $1.0(0-4)$ & $1.5(0-4)$ & 0.141 \\
\hline 12.hour & $0.9(0-4)$ & $1.1(0-3)$ & 0.665 \\
\hline 16.hour & $0.8(0-3)$ & $0.9(0-3)$ & 0.773 \\
\hline 24.hour & $0.5(0-2)$ & $0.5(0-3)$ & 1.000 \\
\hline 1.week & $0.1(0-1)$ & $0.3(0-3)$ & 0.322 \\
\hline \multicolumn{4}{|c|}{ At movement } \\
\hline 30.min & $1.0(0-2)$ & $1.9(0-3)$ & $0.007^{*}$ \\
\hline 1.hour & $1.2(0-3)$ & $1.9(0-3)$ & $0.035^{*}$ \\
\hline 2.hour & $1.4(0-4)$ & $2.6(0-7)$ & $0.022^{*}$ \\
\hline 4.hour & $1.0(0-3)$ & $2.7(0-7)$ & $0.005^{*}$ \\
\hline 8.hour & $1.0(0-4)$ & $1.7(0-7)$ & 0.160 \\
\hline 12.hour & $1.0(0-4)$ & $1.0(0-7)$ & 1.000 \\
\hline 16.hour & $1.3(0-3)$ & $0.8(0-3)$ & 0.217 \\
\hline 24.hour & $0.9(0-3)$ & $0.4(0-2)$ & 0.083 \\
\hline 1.week & $0.6(0-3)$ & $0.2(0-2)$ & 0.134 \\
\hline
\end{tabular}

* statistically significant

When the groups were compared in terms of sedation and postoperative nausea-vomiting (PONV) scores, no statistically significant difference was found.

\section{DISCUSSION}

Including patients undergoing surgery for breast cancer, the present study's results showed that, compared to the ESP block application, PECs 2 block reduced opioid consumption, the amount of rescue analgesic used and the on-movement VAS scores during the intraoperative and postoperative period while also providing longer analgesia time.

When the literature is reviewed, there are many studies on regional analgesia techniques applied to control post-operative pain after breast surgery $7,11,12$. Previously, paravertebral block was considered to be the most effective method in post-operative pain control after breast surgery; however, following the search for safer and more effective regional analgesia techniques, especially US guided techniques such as PECs 2 block and ESP block have gained a wider use in recent years ${ }^{6}$.

There are many studies supporting that both block applications reduce the pain seen after breast surgery ${ }^{13-16}$. Studies have shown that, compared to paravertebral block, both ESP block application and PECs 2block application provide more effective pain management and are safer regional techniques ${ }^{17,18}$.

Cadaveric studies on ESP block application have shown that the distribution of local anesthetic agents is in a wide area that covers the intercostal region and the epidural and neural foramina, but clear data has yet to be retrieved concerning the mechanism of action, the appropriate amount and concentration of local anesthetic agents to be used ${ }^{19}$. Studies on PECs 2 blockreport that the anesthetic agent is distributed along the long thoracic nerves, thoracic intercostal nerves, intercostobrachial nerve and lateral-medial pectoral nerves, thus providing an effective analgesia in the axillary area and the chest wall 5 .

Among the studies on the distribution and 
volume of the local anesthetic agent, a study by Gürkan et al. ${ }^{9}$ stated that ESP block application with $20 \mathrm{ml} 0.25 \%$ bupivacaine at $\mathrm{T} 4$ level provided effective pain control, while another study where Kim et al. ${ }^{20}$ applied PECs 2 block with $30 \mathrm{ml} 0.25 \%$ bupivacaine and emphasized the effective control of postoperative pain, as already supported by previous studies. In our block applications in our study, we preferred to use local anesthetic agents in the amounts and concentrations that the literature confirms to achieve effective pain control.

The distribution area of the local anesthetic agent directly affects the analgesia effect area. In many studies, ESP block application was performed with the patient in a sitting position ${ }^{21}$. Although this position has been shown to reduce the risk of pneumothorax, we believe that the local anesthetic agent can move caudally with the effect of gravity, the analgesic effect may decrease and cause stress in the patient. Therefore, in our study, we performed all our block applications after general anesthesia induction and 15 minutes before the surgical incision. We performed the PECs 2 block application in the supine position, which is the most appropriate position for block application, and the ESP block application in the lateral decubitus position, and when the procedure was completed, we quickly placed the patient in the supine position.

Helander et al. ${ }^{22}$ reported that PECs 2 block application was effective in relieving the pain observed after breast surgery, especially in the early postoperative period. Chandni et al. ${ }^{14}$ compared PECs 2 block and ESP block in patients who underwent breast surgery, and found that there was lower opioid consumption and longer analgesia time in the patients performed PECs 2 block. Again, Altıparmak et al. ${ }^{10}$ found that, compared to ESP block, PECs 2block application achieves more effective pain management, thereby having lower opioid consumption. Our study had consistent results with the literature and found out that, compared to those who received ESP block, the patients who underwent PECs 2 block had lower opioid consumption, longer analgesia time, and less rescue opioid, lower onmovement VAS scores within the first four hours postoperatively.

Bakshi et al. ${ }^{23}$ reported that PECs 2 block application in patients with breast surgery impairs surgical comfort due to complications due to fluid accumulation in the surgical area. In our study, we did not encounter this problem in any patient and there was no surgeon dissatisfaction. Unlike Bakshi et al. we attribute this situation to our 15-minute wait to ensure the formation of sufficient sensory block after applying the block. In this way, the local anesthetic agent is absorbed in the area of the block application in the period until the surgery is initiated and the surgical team reaches the area where the local anesthetic agent has been administered; and therefore, the fluid that is reported to have a negative effect on the surgical comfort is not observed.

Since it causes less opioid use, both PECs 2 block and ESP block cause lower PONV incidence in patients. In our study results, although there was statistically significantly less opioid use in the PECs 2 group, there was no difference between the groups in terms of PONV incidence. We think that this situation is due to the ondansetron effect that we routinely apply to patients in the intraoperative period.

Chronic pain is observed in patients with a rate of $25-60 \%$ after breast surgery ${ }^{24}$. There are studies in the literature showing that the application of PECs 2 block reduces the chronic pain seen after breast surgery ${ }^{25}$. Chiu et al. ${ }^{14}$ applied the block while patients were awake and had the chance to evaluate the sensorial block level. In our study, block applications were performed after general anesthesia. Therefore, the sensorial block level and failed blocks could not be evaluated. The previously- 
studied chronic pain and sensory block level were not evaluated in our study, which is one of our limitations.

\section{CONCLUSION}

In conclusion, in patients who underwent breast surgery for malignancy, we found that the USguided PECs 2 block achieved more effective postoperative analgesia compared to ESP block, since it provided lower pain scores, less opioid use, and longer analgesia time. However, we believe that the literature should be supported with further studies including larger patient populations and evaluating chronic pain.

Ethics Committee Approval: The study was planned to be conducted as a prospectively observational one between the dates 01.03.2020-01.03.2021. The approval of the local ethics committee (28.02.2020-436) was obtained.

Acknowledgements: Thanks to Sedat Kaya, Hakan Akelma and Bahri Çakabay for their contribution to this study.

Conflict of Interest: The authors declared no conflicts of interest.

Financial Disclosure: The authors declared that this study has received no financial support.

\section{REFERENCES}

1. Siegel RL, Miller KD, Jemal A. Cancer statistics, 2016. CA Cancer J Clin. 2016; 66: 7-30.

2. Çiftci F, TolgaKafadar M. The Role Of BreastConserving Surgery In The Treatment Of Early-Stage Breast Cancer. Dicle Med J. 2020; 47: 852-8.

3. Vadivelu N, Schreck M, Lopez PAJ, Kodumudi G, Narayan D. Pain after mastectomy and breast reconstruction. Am Surg. 2008; 74: 285-96.

4. Hussain N, Brull R, McCartney CJL, et al. PectoralisII Myofascial Block and Analgesia in Breast Cancer Surgery: A Systematic Review and Meta-analysis. Anesthesiology. 2019; 131: 630-48.
5. Blanco R, Fajardo M, Parras Maldonado T. Ultrasound description of Pecs II (modified Pecs I): A novel approach to breast surgery. Rev EspAnestesiolReanim. 2012; 59(9): 470-5.

6. Aksu C, Kuş A, Yörükoğlu HU, Tor Kiliç C, Gürkan $Y$. Analgesic effect of the bi-level injection erector spinae plane block after breast surgery: A randomized controlled trial. Agri. 2019; 31: 132-7.

7. He W, Wu Z, Zu L, Sun H, Yang X. Application of erector spinae plane block guided by ultrasound for postoperative analgesia in breast cancer surgery: A randomized controlled trial. Cancer Commun. 2020; 40: $122-25$.

8. Chin KJ, Adhikary S, Sarwani N, Forero M. The analgesic efficacy of pre-operative bilateral erector spinae plane (ESP) blocks in patients having ventral hernia repair. Anaesthesia. 2017; 72: 452-60.

9. Gürkan Y, Aksu C, Kuş A, Yörükoğlu UH, Kılıç CT. Ultrasound guided erector spinae plane block reduces postoperative opioid consumption following breast surgery: A randomized controlled study. J ClinAnesth. 2018; 50(June): 65-8.

10. Altıparmak B, KorkmazToker M, Uysal Aİ, Turan $M$, GümüşDemirbilek S. Comparison of the effects of modified pectoral nerve block and erector spinae plane block on postoperative opioid consumption and pain scores of patients after radical mastectomy surgery: A prospective, randomized, controlled trial. J ClinAnesth. 2019; 54: 61-5.

11. Gad M, Abdelwahab K, Abdallah A, Abdelkhalek M, Abdelaziz M. Ultrasound-guided erector spinae plane block compared to modified pectoral plane block for modified radical mastectomy operations. Anesth Essays Res. 2019; 13: 334.

12. Hussain N, Shastri U, McCartney CJL, et al. Should Thoracic Paravertebral Blocks Be Used to Prevent Chronic Postsurgical Pain after Breast Cancer Surgery? A Systematic Analysis of Evidence in Light of IMMPACT Recommendations. Pain. 2018; 159: 1955-71.

13. Ohgoshi Y, Ikeda T, Kurahashi K. Continuous erector spinae plane block provides effective perioperative analgesia for breast reconstruction using tissue expanders: A report of two cases. J ClinAnesth. 2018; 44: 1-2. 
14. Chiu C, Aleshi P, Esserman LJ, et al. Improved analgesia and reduced post-operative nausea and vomiting after implementation of an enhanced recovery after surgery (ERAS) pathway for total mastectomy. BMC Anesthesiol. 2018; 18: 41.

15. Sinha C, Kumar A, Kumar A, et al. Pectoral nerve versus erector spinae block for breast surgeries: $A$ randomised controlled trial. Indian J Anaesth. 2019; 63: 617.

16. Thomas M, Philip FA, Mathew AP, Jagathnath Krishna KM. Intraoperative pectoral nerve block (Pec) for breast cancer surgery: A randomized controlled trial. J AnaesthesiolClinPharmacol. 2018; 34: 318-23.

17. Kulhari S, Bharti N, Bala I, Arora S, Singh G. Efficacy of pectoral nerve block versus thoracic paravertebral block for postoperative analgesia after radical mastectomy: A randomized controlled trial. Br J Anaesth. 2016; 117: 382-86.

18. Veiga M, Costa D, y IB-RE de A. Erector spinae plane block for radical mastectomy: a new indication. Elsevier. 2018; 65: 112-5.

19. Adhikary S Das, Bernard S, Lopez H, Chin KJ. Erector Spinae Plane Block Versus Retrolaminar Block: A Magnetic Resonance Imaging and
Anatomical Study. RegAnesth Pain Med. 2018; 43: 756-62.

20. Kim DH, Kim S, Kim CS, et al. Efficacy of pectoral nerve block Type II for breast-conserving surgery and sentinel lymph node biopsy: A prospective randomized controlled study. Pain Res Manag. 2018.

21. Versyck B, van Geffen GJ, Van Houwe P. Prospective double blind randomized placebocontrolled clinical trial of the pectoral nerves (Pecs) block type II. J ClinAnesth. 2017; 40: 46-50.

22. Helander EM, Webb MP, Kendrick J, et al. PECS, serratus plane, erector spinae, and paravertebral blocks: A comprehensive review. Best Pract Res ClinAnaesthesiol. 2019; 33: 573-81.

23. Bakshi SG, Karan N, Parmar V. Pectoralis block for breast surgery: A surgical concern? Indian J Anaesth. 2017; 61: 851-52.

24. Andersen KG, Kehlet H. Persistent pain after breast cancer treatment: A critical review of risk factors and strategies for prevention. J Pain. 2011; 12: 725-46.

25. De Cassai A, Bonanno C, Sandei L, et al. PECS II block is associated with lower incidence of chronic pain after breast surgery. Korean J Pain. 2019; 32: 286-91. 